\title{
USE OF WOOD FROM Pinus caribaea var. caribaea AND Pinus caribaea var. bahamensis FOR PRODUCTION OF PARTICLEBOARD PANELS
}

\author{
Setsuo Iwakiri ${ }^{1}$, Alberto Antonio Manhiça ${ }^{2}$, Carlos Frederico Alice Parchen², \\ Everilton José $\mathrm{Cit}^{2}$, Rosilani Trianoski²
}

(received: May 18, 2009; accepted: March 31, 2010)

\begin{abstract}
This study aimed to evaluate the quality of particleboard panels made with wood from Pinus caribaea var. caribaea and Pinus caribaea var. bahamensis, as obtained from forest stands. Experimental panels were produced with a nominal density of $0.70 \mathrm{~g} / \mathrm{cm}^{3}$, using urea-formaldehyde resin and wood particles of Pinus caribaea var. caribaea and Pinus caribaea var. bahamensis, at rates of $100 \% \times 0 \%, 75 \% \times 25 \%, 50 \% \times 50 \%, 25 \% \times 75 \%$ and $0 \% \times 100 \%$. Pinus taeda wood was used as control sample. Panels were compressed at a specific pressure of $40 \mathrm{kgf} / \mathrm{cm}^{2}$ and temperature of $160^{\circ} \mathrm{C}$, for 8 minutes. Analysis results of water absorption, thickness swell, internal bond, modulus of elasticity and modulus of rupture properties indicated feasibility of using wood from Pinus caribaea var. caribaea and Pinus caribaea var. bahamensis for production of particleboard panels, individually or combined at rates of $75 \%, 50 \%$ and $25 \%$.
\end{abstract}

Key words: Tropical pine, wood particles, combined species.

\section{UTILIZAÇÃO DA MADEIRA DE Pinus caribaea var. caribaea E Pinus caribaea var. bahamensis PARA PRODUÇÃO DE PAINÉIS AGLOMERADOS}

\begin{abstract}
RESUMO: Objetivou-se, nesta pesquisa, avaliar a qualidade dos painéis aglomerados produzidos com madeiras de Pinus caribaea var. caribaea e Pinus caribaea var. bahamensis provenientes de plantios florestais. Foram produzidos painéis experimentais com densidade nominal de $0,70 \mathrm{~g} / \mathrm{cm}^{3}$, utilizando a resina uréia-formaldeído e partículas de madeira de Pinus caribaea var. caribaea e Pinus caribaea var. bahamensis, em proporções de $100 \times 0 \%, 75 \times 25 \%$, 50x50\%, 25/75\% e 0x100\%. A madeira de Pinus taeda foi utilizada como testemunha. Os painéis foram prensados com pressão específica de $40 \mathrm{kgf} / \mathrm{cm}^{2}$, temperatura de $160^{\circ} \mathrm{C}$ e tempo de prensagem de 8 minutos. Os resultados das avaliações de propriedades de absorção de água, inchamento em espessura, ligação interna, módulo de elasticidade e módulo de ruptura indicaram a viabilidade de utilização de madeiras de Pinus caribaea var. caribaea e Pinus caribaea var. bahamensis, individualmente, ou em mistura nas proporções de 75, 50 e 25\%, para produção de painéis aglomerados.
\end{abstract}

Palavras-chave: Pinus tropicais, partículas de madeira, mistura de espécies.

\section{INTRODUCTION}

Pinus caribaea is a pine species that comprises three natural varieties, namely caribaea, bahamensis and hondurensis. They are native to Central America Central, naturally occurring in Mexico, Cuba, Bahamas, Belize, Guatemala, Nicaragua and some other local islands, at altitudes ranging from sea level to $1,000 \mathrm{~m}$. Known as 'tropical pine', these trees develop better in hot climates, where they grow faster and better than other species, including Pinus taeda and Pinus elliottii, the latter two developing better in temperate climates with milder temperatures (PORTAL MADEIRA TOTAL 2008).

All Pinus caribaea varieties have great potential for use in reforestations of frost-free, hot climate zones, thus being extensively researched in various regions across the globe for reasons that include pursuit of superior wood quality and production optimization. While hondurensis variety has already been planted on a commercial scale mainly in southeastern Brazil, experimental stands of caribaea and bahamensis varieties are found chiefly in São Paulo, Minas Gerais, Bahia and northern Paraná states (SOCIEDADE BRASILEIRA DE SILVICULTURA-SBS 2007). The wood of Pinus caribaea is particularly suitable for production of sawnwood, laminations, plywood, particleboard and MDF.

In Brazil, manufacturers of particleboard panels use Pinus taeda, Pinus elliottii and some species of genus Eucalyptus, grown in forest stands, as sources of raw material. They require massive amounts of wood to produce panels and thus need continuous, large-scale investments to establish new forest production areas.

${ }^{1}$ Forest Engineer, Professor, Ph.D. in Forest Engineering - Departamento de Engenharia e Tecnologia Florestal/DETF - Universidade Federal do Paraná/UFPR - 80210-170 - Curitiba, PR - setsuo@ufpr.br

${ }^{2}$ Student of the Forest Engineering Graduate Program/PPGEF - Universidade Federal do Paraná/UFPR - Av. Lothário Meissner, 632 Jardim Botânico - 80210-170 - Curitiba, PR - albertomanhica@yahoo.com.br, parchen@ufpr.br, everilton@yahoo.com.br, rosillani@gmail.com 
Some physical and chemical properties of wood, including density, $\mathrm{pH}$ and extractives, directly influence the production process and the quality of finished particleboard panels (MALONEY 1994, MARRA 1992). According to these authors, the $\mathrm{pH}$ and also extractives present in the wood can influence the resin curing process and, consequently, panel quality. Woods with an excessively acidic $\mathrm{pH}$ can speed up the curing process of urea-formaldehyde resin during the compression phase, with implications for the finished panel properties. From another standpoint, where phenol-formaldehyde resin is used for production of structural panels, woods with a low $\mathrm{pH}$ can delay the resin curing process (KELLY 1977).

Wood density is a basic requirement to meet when selecting species for particleboard production, as it directly influences the compaction ratio of panels. According to Moslemi (1974), compaction ratio is the relationship between panel density and wood density, and it should be at least 1.3 to ensure sufficient compaction for panel formation. Kelly (1977) argues that, with finished panels of the same density, those produced with lower density wood, while having less dimensional stability, will have superior mechanical properties than those produced with higher density wood. According to the author, panels with a higher compaction ratio contain a larger amount of wood particles and consequently present greater compaction, resulting in improved hygroscopic swell of the wood and better release of the compression tension generated during the pressing process.

Combining different species to form particleboard panels is a very important step in order to expand supply possibilities of raw material to manufacturers requiring large amounts of timber. Moslemi (1974) developed a formula to calculate average wood density resulting from a combination of species of different densities:

$\mathrm{Wd}=\left[\mathrm{Wd}_{1} \times(\%)+\mathrm{Wd}_{2} \times(\%)+\ldots .+\mathrm{Wd}_{\mathrm{n}} \times(\%)\right]: \mathrm{n}$

Where:

$\mathrm{Wd}$ : density of resulting wood

$\mathrm{Wd}_{1,2, \ldots \mathrm{n}}$ : wood density of each species

(\%): percentage of a species in the mixture

$\mathrm{n}$ : number of species

Application of the above formula can enable use of wood species of higher densities in combination with wood species of lower densities, yet ensuring the compaction ratio is maintained within the acceptable range.

Cerne, Lavras, v. 16, n. 2, p. 193-198, abr./jun. 2010
Several studies have been performed to evaluate the quality of particleboard panels from combined species. Iwakiri et al. (1996) analyzed the influence of combined wood particles of Pinus taeda and Eucalyputs dunnii-at rates of $100 \%, 75 \%, 50 \%, 25 \%$ and $0 \%$ of pine to eucalyptus - on properties of experimental particleboard panels. Results indicated the possibility of using Eucalyputs dunnii at rates of up to $50 \%$ without affecting their physical and mechanical properties.

The objective of this work is thus to evaluate the quality of particleboard panels made with wood from Pinus caribaea var. caribaea and Pinus caribaea var. bahamensis at different combination rates.

\section{MATERIAL AND METHODS}

The material used in this study included woods from Pinus caribaea var. caribaea and Pinus caribaea var. bahamensis, at age 17 years, obtained from forest stands in the municipality of Ventania, in Paraná state. Wood from Pinus taeda was used as control sample, as it is the most widely used species in industrial production of particleboard panels in Brazil.

Logs of Pinus caribaea var. caribaea and Pinus caribaea var. bahamensis were processed into boards one inch thick and then transported to the study site. Wood of Pinus taeda was obtained in the form of fragments from Berneck S/A Painéis e Serrados, a particleboard panel manufacturer located in the municipality of Araucária, Paraná state. For particle bonding, a urea-formaldehyde resin was used with a solids content of $65 \%$, a $\mathrm{pH}$ of 7.8 and Brookfield viscosity of $420 \mathrm{cP}$.

The particleboard panels were produced on a laboratory scale, following the experimental design illustrated in Table 1.

Table 1 - Experimental design.

Tabela 1 - Plano experimental.

\begin{tabular}{ccc}
\hline Treatment & Species & Rate of Content \\
\hline T1 & Pt & $100 \%$ \\
T2 & Pcc & $100 \%$ \\
T3 & Pcb & $100 \%$ \\
T4 & Pcc / Pcb & $75 \% / 25 \%$ \\
T5 & Pcc / Pcb & $50 \% / 50 \%$ \\
T6 & Pcc / Pcb & $25 \% / 75 \%$ \\
\hline
\end{tabular}

Pt: Pinus taeda; Pcc: Pinus caribaea var. caribaea; Pcb: Pinus caribaea var. bahamensis. 
Wood flakes were obtained using a disc chipper, with nominal size of $25 \mathrm{~mm}$ in length, $0.7 \mathrm{~mm}$ in thickness and variable width. Once dry to a moisture content of $3 \%$, the flakes were reduced using a hammer mill and then graded using 0.6 mesh sieves. The Pinus taeda fragments obtained from the panel manufacturer were also reduced using a hammer mill and then sieved using the same procedures as used for Pinus caribaea, to standardize particle size.

After being catalyzed with ammonium sulfate, the liquid resin was applied to the particles at a rate of $8 \%$ solids content in relation to dry particle weight. A $50 \times 50 \mathrm{~cm}$ perforated forming box was used to form each particleboard mat. Calculations were made to define the amount of material required to form a panel, based on $0.70 \mathrm{~g} / \mathrm{cm}$ of nominal density and $50 \times 50 \times 1.5 \mathrm{~cm}$ panel size. The panels were compressed at a temperature of $160^{\circ} \mathrm{C}$ and specific pressure of $40 \mathrm{kgf} / \mathrm{cm}^{2}$, for 8 minutes. Two panels were made per treatment, to a total of twelve experimental panels.

Once pressed, panels were bracket sawn and stored in an environmental chamber at $20 \pm 2^{\circ} \mathrm{C}$ and $65 \pm 3 \% \mathrm{RH}$ till they reached an average $12 \%$ moisture content.

To assess physical and mechanical properties, each panel had four samples taken and submitted to static bending tests, five samples taken and submitted to internal bond tests, and five samples taken and submitted to water absorption and thickness swell tests after 24 hours of immersion in water. Tests were performed according to procedures described in European Standards EN 310, EN 319 and EN 317 respectively.

Statistical analysis was based on a completely randomized design and results were assessed using analysis of variance and the Tukey test at the $95 \%$ probability level.

\section{RESULTS AND DISCUSSION}

\subsection{Compaction ratio}

Average densities of Pinus taeda, Pinus caribaea var. caribaea and Pinus caribaea var. bahamensis were $0.420 \mathrm{~g} / \mathrm{cm}^{3}, 0.398 \mathrm{~g} / \mathrm{cm}^{3}$ and $0.429 \mathrm{~g} / \mathrm{cm}^{3}$ respectively. Table 2 illustrates panel density and average density of combined particles of var. caribaea and var. bahamensis at different rates, based on the formula proposed by Moslemi (1974).

Treatment T4, with $75 \%$ of var. caribaea and $25 \%$ of var. bahamensis, showed average wood density of $0.405 \mathrm{~g} / \mathrm{cm}^{3}$. Treatments T5 and T6, with combined particles at $50 \% \times 50 \%$ and $25 \% \times 75 \%$ of var. caribaea to var. bahamensis, average wood densities were $0.413 / \mathrm{cm}^{3}$ and $0.420 \mathrm{~g} / \mathrm{cm}^{3}$ respectively.

Compaction ratio values, as derived from the relationship between panel density and wood density, ranged from 1.526 to 1.726 . Panels with $100 \%$ of var. caribaea showed the highest compaction ratio value, while the lowest compaction ratio value was provided by combined $25 \%$ of var. caribaea and $75 \%$ of var. bahamensis. It is noted that increasing rates of var. caribaea in relation to var. bahamensis result in increased compaction ratio. While studying particleboard panels from combined Pinus taeda and Eucalyptus dunnii, Iwakiri et al. (1996) found compaction ratio values ranging from 1.03 to 1.74 with increasing rates of Pinus taeda in relation to Eucalyptus dunnii.

\subsection{Physical properties of panels}

Water absorption values after 24 hours of immersion in water are illustrated in Table 3 and indicate no statistically significant differences between mean values of panels from Pinus taeda, Pinus caribaea var. caribaea and var. bahamensis and between combinations of these two varieties.

Table 2 - Wood density, panel density and compaction ratio.

Tabela 2 - Densidade da madeira, densidade dos painéis e razão de compactação.

\begin{tabular}{|c|c|c|c|}
\hline Treatment & $\mathrm{WD}\left(\mathrm{g} / \mathrm{cm}^{3}\right)$ & $\mathrm{PD}\left(\mathrm{g} / \mathrm{cm}^{3}\right)$ & $\mathrm{CR}$ \\
\hline T1 - Pt 100 & 0.420 & $0.676 \mathrm{~A}$ & 1.609 \\
\hline $\mathrm{T} 2-\mathrm{Pcc} 100$ & 0.398 & $0.687 \mathrm{~A}$ & 1.726 \\
\hline T3 - Pcb 100 & 0.429 & $0.694 \mathrm{~A}$ & 1.618 \\
\hline $\mathrm{T} 4-\mathrm{Pcc} 75 / \mathrm{Pcb} 25 *$ & 0.405 & $0.661 \mathrm{~A}$ & 1.632 \\
\hline $\mathrm{T} 5-\mathrm{Pcc} 50 / \mathrm{Pcb} 50 *$ & 0.413 & $0.685 \mathrm{~A}$ & 1.658 \\
\hline T6 - Pcc $25 /$ Pcb $75 *$ & 0.420 & $0.641 \mathrm{~A}$ & 1.526 \\
\hline
\end{tabular}

Pt: Pinus taeda; Pcc: Pinus caribaea var. caribaea; Pcb: Pinus caribaea var. bahamensis; WD: wood density; PD: panel density; CR: compaction ratio. Means followed by the same letter in the column are statistically similar at the $95 \%$ probability level by the Tukey test. 
Table 3 - Water absorption and thickness swell values after 24 hours of immersion.

Tabela 3 - Resultados de absorção de água e inchamento em espessura - 24 horas.

\begin{tabular}{lcc}
\hline Treatment & WA $-24 \mathrm{H}(\%)$ & TS $-24 \mathrm{H}(\%)$ \\
\hline \multirow{2}{*}{ T1-Pt 100 } & $90.67 \mathrm{~A}$ & $26.93 \mathrm{BC}$ \\
& $(8.81)$ & $(8.91)$ \\
T2-Pcc 100 & $88.93 \mathrm{~A}$ & $31.34 \mathrm{~A}$ \\
& $(10.57)$ & $(5.96)$ \\
T3-Pcb 100 & $83,74 \mathrm{~A}$ & $25,35 \mathrm{BC}$ \\
& $(8,38)$ & $(8,55)$ \\
T4-Pcc 75 / Pcb 25 & $91.81 \mathrm{~A}$ & $27.75 \mathrm{~B}$ \\
& $(8.48)$ & $(14.81)$ \\
T5-Pcc 50 / Pcb 50 & $88.30 \mathrm{~A}$ & $28.86 \mathrm{AB}$ \\
& $(4.90)$ & $(8.11)$ \\
T6-Pcc 25 / Pcb 75 & $92.00 \mathrm{~A}$ & $24.00 \mathrm{C}$ \\
& $(5.94)$ & $(9.75)$ \\
\hline
\end{tabular}

Pt: Pinus taeda; Pcc: Pinus caribaea var. caribaea; Pcb: Pinus caribaea var. bahamensis; WA: water absorption; TS: thickness swell; ( ... ) coefficient of variation (\%).Means followed by the same letter in the column are statistically similar at the $95 \%$ probability level by the Tukey test.

Mean values of $83.74 \%$ to $92.00 \%$ for water absorption are compatible with values found by Iwakiri et al. (2001) while studying panels from five species of tropical pine with no paraffin emulsion applied, which ranged from $75.04 \%$ to $80.05 \%$. Dacosta et al. (2005a) found mean values of $75.67 \%$ to $90.85 \%$ for water absorption after 24 hours while studying particleboard panels from Pinus elliottii with densities of 0.60 and $0.70 \mathrm{~g} / \mathrm{cm}^{3}$. Iwakiri et al. (2000) found means values of $29.24 \%$ to $67.32 \%$ for water absorption after 24 hours while studying particleboard panels from Eucalyptus saligna, Eucalyptus citriodora and Eucalyptus pilularis.

As for thickness swell after 24 hours, the highest mean value was noted for panels made exclusively with Pinus caribaea var. caribaea. No statistically significant differences were noted between panels from Pinus taeda and Pinus caribaea var. bahamensis. As for those made with combined varieties of Pinus caribaea, the lowest thickness swell value was noted for the combination $25 \%$ of caribaea and $75 \%$ of bahamensis, with differences being statistically significant.

With panels from the above mentioned five species of tropical pine, Iwakiri et al. (2001) found mean values of $32.70 \%$ to $39.74 \%$ for thickness swell after 24 hours. Dacosta et al. (2005a) found mean values of $23.50 \%$ to $40.04 \%$ for thickness swell in particleboard panels from Pinus elliottii with densities of 0.60 and $0.70 \mathrm{~g} / \mathrm{cm}^{3}$. Iwakiri et al. (2000) found mean values of $23.07 \%$ to $45.35 \%$ for thickness swell after 24 hours in particleboard panels from Eucalyptus saligna, Eucalyptus citriodora and Eucalyptus pilularis.

\subsection{Mechanical properties of panels}

Mean values of internal bond are illustrated in Table 4 and indicate a variation range of $0.58 \mathrm{MPa}$ to $1.30 \mathrm{MPa}$ among the six treatments in question. All values are above the minimum $0.35 \mathrm{MPa}$ requirement established by European Standard EN 312-3 (European Committee for Standardization 1993).

It should be noted that all panels made with Pinus caribaea var. caribaea and var. bahamensis and with a combination of the two derived mean values of internal bond statistically higher than those made with Pinus taeda. No significant differences were found between panels made with $100 \%$ of var. caribaea and var. bahamensis, and combinations of the two, except treatment T6 with $25 \%$ of var. caribaea and $75 \%$ of var. bahamensis, which showed a higher mean value of internal bond than panels made with $100 \%$ of var. caribaea.

As reference parameters in existing literature, Iwakiri et al. (2001) found mean values of internal bond of 0.72 $\mathrm{MPa}$ to $1.05 \mathrm{MPa}$ for panels made with five species of tropical pine. Cabral et al. (2007) found mean values of internal bond of $0.45 \mathrm{MPa}$ and $0.56 \mathrm{MPa}$ for panels made with combinations of Eucalyptus urophylla and Pinus elliottii, and Eucalyptus cloeziana and Pinus ellotti respectively. Dacosta et al. (2005b) found mean values of internal bond of 0.13 MPa to 0.20 MPa for particleboard panels of Pinus elliottii with densities of 0.60 and $0.70 \mathrm{~g} /$ $\mathrm{cm}^{3}$. Therefore, results obtained in this study can be considered highly satisfactory.

Modulus of elasticity (MOE) results are illustrated in Table 4 and indicate that the mean value obtained for Pinus caribaea var. caribaea is statistically similar to var. bahamensis and higher than for Pinus taeda. The mean value of MOE for panels from Pinus caribaea var. bahamensis was statistically higher than for panels from Pinus taeda. No significant differences were observed between mean values of MOE for panels made with combined Pinus caribaea var. caribaea and var. bahamensis. It should be noted that, in terms of absolute means, the mean value of MOE for control panels made with Pinus taeda (T1) was well below mean values obtained for other treatments, except treatment T3 with $100 \%$ of var. bahamensis. 
Table 4 - Internal bond, modulus of elasticity and modulus of rupture results.

Tabela 4 - Resultados de ligação interna, módulo de elasticidade e módulo de ruptura.

\begin{tabular}{|c|c|c|c|}
\hline Treatment & IB (MPa) & MOE (MPa) & MOR (MPa) \\
\hline $\mathrm{T} 1-\mathrm{Pt} 100$ & $\begin{array}{c}0.58 \mathrm{C} \\
(11.38)\end{array}$ & $\begin{array}{l}1.886 \mathrm{~B} \\
(19.32)\end{array}$ & $\begin{array}{l}12.03 \mathrm{~B} \\
(22.93)\end{array}$ \\
\hline $\mathrm{T} 2-\operatorname{Pcc} 100$ & $\begin{array}{c}1.07 \mathrm{~B} \\
(22.83)\end{array}$ & $\begin{array}{c}2.326 \mathrm{AB} \\
(29.64)\end{array}$ & $\begin{array}{c}16.73 \mathrm{~A} \\
(16.79)\end{array}$ \\
\hline T3 - Pcb 100 & $\begin{array}{c}1.14 \mathrm{AB} \\
(12.49)\end{array}$ & $\begin{array}{l}2.515 \mathrm{~A} \\
(15.71)\end{array}$ & $\begin{array}{c}18.08 \mathrm{~A} \\
(22.45)\end{array}$ \\
\hline T4 - Pcc 75 / Pcb 25 & $\begin{array}{c}1.16 \mathrm{AB} \\
(7.47)\end{array}$ & $\begin{array}{c}2.140 \mathrm{AB} \\
(16.58)\end{array}$ & $\begin{array}{c}16.80 \mathrm{~A} \\
(19.93)\end{array}$ \\
\hline T5 - Pcc 50 / Pcb 50 & $\begin{array}{c}1.20 \mathrm{AB} \\
(15.18)\end{array}$ & $\begin{array}{c}2.147 \mathrm{AB} \\
(9.86)\end{array}$ & $\begin{array}{l}16.81 \mathrm{~A} \\
(13.02)\end{array}$ \\
\hline T6 - Pcc 25 / Pcb 75 & $\begin{array}{l}1.30 \mathrm{~A} \\
(6.61)\end{array}$ & $\begin{array}{c}2.105 \mathrm{AB} \\
(15.12)\end{array}$ & $\begin{array}{c}16.36 \mathrm{AB} \\
(18.58)\end{array}$ \\
\hline
\end{tabular}

Pt: Pinus taeda; Pcc: Pinus caribaea var. caribaea; Pcb: Pinus caribaea var. bahamensis; IB: internal bond; MOE: modulus of elasticity; MOR: modulus of rupture; ( ... ) coefficient of variation (\%).Means followed by the same letter in the column are statistically similar at the $95 \%$ probability level by the Tukey test.

Mean values of MOE ranged from 1.887 $\mathrm{MPa}$ to 2.515 $\mathrm{MPa}$, which is above the minimum $1.600 \mathrm{MPa}$ requirement established by European Standard EN 312-3: 1996.

Reference MOE values in existing literature are very wide ranging. Iwakiri et al. (1996) found mean values of 2.208 MPa to 2.530 MPa for panels made with combined Pinus taeda and Eucalyptus dunnii at rates 75\%, 50\% and $25 \%$. In another study with five species of tropical pine, Iwakiri et al. (2001) obtained mean values of MOE of 2.563 Mpa to 3.214 MPa. Dacosta et al. (2005b) found mean values of MOE ranging from $522 \mathrm{MPa}$ to $650 \mathrm{MPa}$ for particleboard panels from Pinus elliottii with densities of 0.60 and $0.70 \mathrm{~g} / \mathrm{cm}^{3}$.

According to Table 4 data, mean values of modulus of rupture (MOR) ranged from 12.03 MPa to 16.65 MPa. Except for panels from Pinus taeda, all other panels made with Pinus caribaea var. caribaea and var. bahamensis showed mean values of MOR above the minimum $13 \mathrm{MPa}$ requirement established by European Standard EN 312-3 (1996).

Mean values of MOR for panels made exclusively with Pinus caribaea var. caribaea and var. bahamensis were statistically higher than for Pinus taeda. No statistically significant differences were found between mean values of MOR for panels made exclusively with Pinus caribaea var. caribaea and var. bahamensis or with the two combined.
MOR values found in this study are compatible with reference values in literature. Cabral et al. (2007) found MOR values of 16.7 MPa and 17.9 MPa for panels made with combinations of E. urophylla and P. elliottii, and E. cloeziana and $P$. elliottii respectively. Iwakiri et al. (2004) obtained a mean value of MOR of $10.3 \mathrm{MPa}$ for particleboard panels from Grevilea robusta. Batista et al. (2007) found a MOR value of 5.0 MPa for panels made with combined $P$. elliottii wood and $10 \%$ of E. pellita bark, a value considered low due to the negative influence of bark presence in their composition. In another study, Iwakiri et al. (2001) found mean values of MOR of 17.18 $\mathrm{MPa}$ to $21.54 \mathrm{MPa}$ for panels produced with five species of tropical pine.

\section{CONCLUSIONS}

Based on the above results, the following conclusions can be drawn:

- the compaction ratio of particleboard panels made with the two varieties of $P$. caribaea and with both combined significantly influenced some thickness swell and internal bond results. As for properties water absorption, MOE and MOR under static bending, no significant differences were observed;

- the physical properties of panels made with Pinus caribaea var. caribaea and var. bahamensis were satisfactory in comparison to control panels from Pinus

Cerne, Lavras, v. 16, n. 2, p. 193-198, abr./jun. 2010 
taeda, except the thickness swell of panels made with $25 \%$ of var. caribaea and $75 \%$ of var. bahamensis;

- panels made with Pinus caribaea var. caribaea and var. bahamensis provided better internal bond, MOE and MOR results than control panels from Pinus taeda;

- in comparing the two varieties of Pinus caribaea, in terms of absolute means, var. bahamensis provided higher values of physical and mechanical properties than var. caribaea;

- results of mechanical properties for all experimental panels, from both species and from the two combined, did reach the minimum requirement established by European Standard EN 312-3 (1996).

\section{ACKNOWLEDGEMENTS}

We wish to thank Valor Florestal S.A. and Hexion Química Indústria e Comércio Ltda. for providing the wood and resin used in this research.

\section{BIBLIOGRAPHICAL REFERENCES}

BATISTA, D. C.; BRITO, E. O.; SETUBAL, V. G.; GÓES, L. G. Fabricação de aglomerados de três camadas com madeira de Pinus elliottii Engel,. E casca de Eucalyptus pellita F. Muell. Cerne, Lavras, v. 13, n. 2, p. 178-187, abr./jun. 2007.

CABRAL, C. P.; VITAL, B. R.; LUCIA, R. M. D.; PIMENTA, A. S. Propriedades de chapas de aglomerado confeccionadas com misturas de partículas de Eucalyptus spp e Pinus elliottii. Revista Árvore, Viçosa, v. 31, n. 5, p. 897-905, 2007.

DACOSTA, L. P. E.; HASELEIN, C. R.; SANTINI, E. J.; SCHNEIDER, P. R.; CALEGARI, L. Qualidade das chapas de partículas aglomeradas fabricadas com resíduos do processamento mecânico da madeira de Pinus elliottii Engelm. Ciência Florestal, Santa Maria, v. 15, n. 3, p. 311-322, 2005 a.

DACOSTA, L. P. E.; HASELEIN, C. R.; SANTINI, E. J.; SCHNEIDER, P. R.; CALEGARI, L. Propriedades físicas de chapas de partículas aglomeradas fabricadas com resíduos do processamento mecânico da madeira de Pinus elliottii Engelm. Ciência Florestal, Santa Maria, v. 15, n. 4, p. 421-429, 2005 b.

EUROPEAN COMMITTEE FOR STANDARDIZATION. Norma EN. 1993.

Cerne, Lavras, v. 16, n. 2, p. 193-198, abr./jun. 2010
IWAKIRI, S.; CRUZ, C. R.; OLANDOSKI, D. P.; BRAND, M. A. Utilização de resíduos de serraria na produção de chapas de madeira aglomerada de Eucalyptus saligna, Eucalyptus citriodora, Eucalyptus pilularis. Floresta e Ambiente, Seropédica, v. 7, n. 1, p. 251-256, 2000.

IWAKIRI, S.; LATORRACA, J. V. F.; SILVA, D. A.; GABARDO, J. L.; KLITZKE, R. J.; FOFANO, A.; FABROWSKI, F.; INTERANMENSE, M. T. Produção de chapas de aprtículas de Madeira aglomerada de Pinus elliottii (Engelm) e Eucalyptus dunnii (Maid). Ciências Agrárias, Curitiba, v. 15, n. 1, p. 33-41, 1996.

IWAKIRI, S.; SHIMIZU, J.; SILVA, J. C.; DEL MENEZZI, C. H. S.; PUEHRINGER, C. A.; VENSON, I.; LAROCA, C. Produção de painéis de Madeira aglomerada de Grevilea rovusta A. Cunn. Ex R. Br. Revista Árvore, Viçosa, v. 28, n. 6, p. 56-60, 2004.

IWAKIRI, S.; SILVA, J. R. M.; MATOSKI, S. L. S.; LEONHARDT, G.; CARON, J. Produção de chapas de madeira aglomerada de cinco espécies de pinus tropicais. Floresta e Ambiente, Seropédica, v. 8, n. 1, p. 137-142, 2001.

KELLY, M. W. Critical literature review of relationships between processing parameters and physical properties of particleboard. Washington: USDA, 1977. 66 p.

MALONEY, T. M. Modern particleboard and dry-process fiberboard manufacturing. 2. ed. São Francisco: M. Freeman, 1993. $689 \mathrm{p}$

MARRA, F. S. Tecnhonology of wood bonding: principles in practice. New York: V.N. Reinhold, 1992. 453 p.

MOSLEMI, A. A. Particleboard: materials. London: Southern Illinois University, 1974. v. 1, 244 p.

PORTAL MADEIRA TOTAL. O Pinus no Brasil: Pinus caribaea e suas três variedades - caribaea, bahamensis e hondurensis. 2005. Disponível em: < Acesso em: 18 ago. 2008.

SOCIEDADE BRASILEIRA DE SILVICULTURA. Fatos e números do Brasil Florestal - 2007. 2008. Disponível em: Lwwww.sbs.org.bry. 